\title{
Bioenergetics and metabolic patterns in early onset severe sepsis or trauma
}

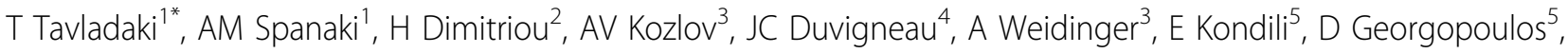 \\ G Briassoulis $^{1}$
}

From ESICM LIVES 2015

Berlin, Germany. 3-7 October 2015

\section{Introduction}

Mitochondrial respiration in vitro is inhibited in severe illness. The mitochondria are one of the major targets for NO.

\section{Objectives}

We examined the first 24-hours differences of ATP, $\mathrm{NO}_{2}{ }^{-}$ and $\mathrm{NO}_{3}{ }^{-}$in patients with severe sepsis (SS) or traumarelated systemic inflammatory response syndrome (SIRS) compared to healthy-controls $(\mathrm{H})$ and examined their relations to intracellular heat shock proteins (HSP)-72 and $-90 \alpha$, metabolism and outcome.

\section{Methods}

Seventy-eight adults (SS/22; non-infectious SIRS /23; healthy $(\mathrm{H}) / 33)$ were included in our study. Energy expenditure (EE) of patients was measured with the Gas Module E-COVX. Patients were classified as hypermetabolic, normometabolic, and hypometabolic when the $\mathrm{EE}$ were $>110 \%, 90-110 \%$ and, $<90 \%$ of the predicted basal metabolic rate, respectively. HSPs expressions in monocytes (m) or neutrophils (n) and the levels of amino acids in plasma were determined using flow cytometry and HPLC, respectively. ATP concentrations were measured by the luciferase luminescent assay. $\mathrm{NO}_{2}{ }^{-}$and $\mathrm{NO}_{3}{ }^{-}$determination was performed using the Sievers Nitric Oxide Analyzer.

\section{Results}

SS and SIRS patients predominantly manifested hypometabolic (SS 41\%, SIRS 65\%) or hypermetabolic (SS 41\%, SIRS 17.4\%) rather than normometabolic pattern (SS $18.2 \%$ vs. $17.4 \%$ ). The hypometabolic pattern was

'University of Crete/University Hospital, PICU, Heraklion, Greece

Full list of author information is available at the end of the article associated with increased mortality $(\mathrm{p}<0.01)$; accompanied by decreased concentrations of arginine, citruline, glutamine $(\mathrm{p}<0.04)$ and mHSP72 and nHSP72 expression $(\mathrm{p}<0.03)$. Patients with SS had lower ATP $(184 \pm 133$ vs. $895 \pm 863 \mathrm{nM})$, and $\mathrm{NO}^{-}(211 \pm 56$ vs. $280 \pm 53 \mathrm{nM}, \mathrm{p}<$ $0.03)$ and SIRS patients lower $\mathrm{NO}^{-}(\mathrm{p}<0.005)$ and $\mathrm{NO}^{-}$ $(\mathrm{p}<0.02)$ compared to controls. Comparison between SS and SIRS showed, that SS had repressed mHSP72 ( $\mathrm{p}<$ $0.002)$ and nHSP72 expression ( $<0.01)$, decreased SID $(\mathrm{p}<0.03)$ and increased NO3 ${ }^{-}$levels $(\mathrm{p}<0.01)$. ATP was correlated with glutamine $(\mathrm{p}<0.05), \mathrm{NO}^{-}$with citruline $(\mathrm{p}<0.03)$ and glucine $(\mathrm{p}<0.05)$, and $\mathrm{NO}^{-}$with the metabolic pattern $(\mathrm{p}<0.05)$, CRP $(\mathrm{p}<0.02)$, SAPS3 $(\mathrm{p}<0.02)$ and inversely with $\mathrm{pH}(\mathrm{p}<0.002)$.

\section{Conclusions}

Early ons et hypometabolism and bioenergitic failure characterize critical illness and are related to intracellular HSP72 repression, severity of illness and outcome. The patterns of $\mathrm{NO}$ metabolites in plasma suggest that the changes in ATP and HSP72 are linked to NO metabolism.

\section{Grant Acknowledgment}

This research has been co-financed by the European Union (European Social Fund (ESF)) and Greek national funds through the Operational Program "Education and Lifelong Learning" of the National Strategic Reference Framework (NSRF)-Research Funding Program: THALES.

\footnotetext{
Authors' details

${ }^{1}$ University of Crete/University Hospital, PICU, Heraklion, Greece. ${ }^{2}$ University of Crete, Medical School, Paediatric Haematology Oncology, Heraklion, Greece. ${ }^{3}$ Ludwig Boltzmann Institute for Experimental and Clinical Traumatology in the AUVA, Vienna, Austria. ${ }^{4}$ University of Veterinary Medicine, Vienna, Austria. ${ }^{5}$ University of Crete/University Hospital, ICU, Heraklion, Greece.
} 


\section{Submit your manuscript to a SpringerOpen ${ }^{\mathcal{O}}$ journal and benefit from:}

- Convenient online submission

- Rigorous peer review

- Immediate publication on acceptance

- Open access: articles freely available online

- High visibility within the field

- Retaining the copyright to your article

Submit your next manuscript at $\gg$ springeropen.com 